\title{
Meningkatkan Prestasi Belajar Pkn Materi Proses Pemilu Dengan Metode Bermain Peran Siswa Kelas VI Semester I SDN Jango Kecamatan Janapria Tahun Pelajaran 2015/2016
}

\author{
Suharti \\ SDN Jango Kecamatan Janapria lombok Tengah
}

\begin{abstract}
Abstrak. Hasil pengamatan di dalam kelas saat pembelajaran PKn berlangsung, siswa kelas VI cenderung pasif dan aktivitas belajar PKn siswa sangatlah kurang. Untuk pelajaran PKn nilai rata-rata yang diperoleh siswa kelas VI pada materi Organisasi dilingkungan sekolah dan Masyarakat merupakan materi sebelum dilakukannya penelitian ini adalah 67,46. dan persentase jumlah siswa yang mencapai standar ketuntasan belajar sebesar 34,62 \% Nilai ini sangatlah jauh dari persentase jumlah siswa yang mencapai standar ketuntasan belajar mengajar (SKBM) yang ditetapkan di SD Negeri Jango, yaitu sebesar 85\%. Penelitian tindakan kelas (PTK) ini dilaksanakan selama 3 Bulan dengan menggunakan metode Bermain Peran dalam upaya meningkatkan Hasil belajar PKn siswa kelas VI SD Negeri Jango Penelitian dilaksanakan dalam dua siklus masing-masing terdiri dari dua pertemuan melalui tahapan-tahapan sebagai berikut perencanaan, tindakan obervasi dan refleksi. Teknik pengumpulan data dilakukan melalui lembar pengamatan tiap pertemuan oleh observer untuk melihat data tentang aktivitas belajar, sementara data tentang hasil belajar diperoleh melalui nilai ulangan harian dan prestasi belajar PKn siswa di siklus 1, dan disiklus 2. Hasil yang diperoleh dari Penelitian Tindakan Kelas (PTK) melalui model metode Bermain Peran memperlihatkan peningkatan hasil aktivitas guru 77,63 \% ,aktifitas siswa 62,50 \% dan Prestasi belajar 73,27 \% sedangkan pada siklus II. aktivitas guru 93,43\% ,aktifitas siswa 93,73\% dan Prestasi belajar 80,58 \% Presentase jumlah siswa yang mencapai standar ketuntasan juga meningkat pada siklus I sebesar 61,54\% (Kategori Baik), meningkat menjadi 96,15\% (Kategori Istimewa) pada siklus II.
\end{abstract}

Kata kunci : Metode Bermain Peran, Hasil Belajar PKn

\section{PENDAHULUAN}

\section{Latar Belakang}

Pendidikan Kewarganegaraan ( PKn ) diberikan sejak SD sampai SLTA. Dengan PKn seseorang akan memiliki kemampuan untuk mengenal dan memahami karakter dan budaya bangsa serta menjadikan warga negara yang siap bersaing di dunia internasional tanpa meninggalkan jati diri bangsa. Melalui PKn setiap warga Negara dapat mawas diri dengan perkembangan teknologi informasi dan komunikasi dewasa ini yang memberi dampak positif dan negatif. PKn juga bermanfaat untuk membekali Siswa agar memiliki kemampuan untuk mengelola dan memanfaatkan informasi untuk bertahan hidup pada keadaan yang selalu berubah, tidak pasti dan kompetitif.

Pada kenyataannya, PKn dianggap ilmu yang sukar dan sulit dipahami. PKn adalah pelajaran formal yang berupa sejarah masa lampau, perkembangan social budaya, perkembangan teknologi, tata cara hidup bersosial, serta peraturan kenegaraan. Begitu luasnya materi PKn menyebabkan anak sulit untuk diajak berfikir kritis dan kreatif dalam menyikapi masalah yang berbeda. Sementara anak usia Sekolah Dasar tahap berfikir mereka masih belum formal, karena mereka baru berada pada tahap Operasional Konkret Mulyasa (2007)' Apa yang dianggap logis, jelas dan dapat dipelajari bagi orang dewasa, kadang - kadang merupakan hal yang tidak masuk akal dan membingungkan bagi Siswa. Akibatnya banyak Siswa yang tidak memahami konsep PKn.

Berdasarkan temuan penulis, sebagian besar Siswa kurang aktif dan kurang berfikir kritis dalam materi Proses Pemilu.Apabila anak menghadapi masalah kontekstual baru yang berbeda dengan yang dicontohkan, anak belum mampu berfikir kritis dan menemukan 
solusi dengan benar sehingga banyak anak yang menjawab salah, dan dengan alasan soalnya sulit. Karena itu wajar setiap kali diadakan tes, nilai pelajaran $\mathrm{PKn}$ selalu rendah dengan nilai rata - rata dibawah KKM.

Seperti yang dialami penulis sendiri, setiap ulangan $\mathrm{PKn}$ nilai rata - rata anak <75.Termasuk pada materi Proses Pemilu, Nilai rata - rata formatif hanya 67,46. Dari 26 Siswa hanya 9 Siswa atau $34,62 \%$ yang memperoleh nilai $75 \mathrm{ke}$ atas. Sedangkan 17 Siswa atau 65,38\% yang mendapat nilai di bawah 75 .

Menghadapi kenyataan tersebut di atas, penulis tertarik untuk mendalami dan melakukan tindakan - tindakan perbaikan pembelajaran PKn, khususnya materi Proses Pemilu melalui penelitian tindakan kelas. Perbaikan yang penulis lakukan mengenai penerapan metode bermain peran pada materi Proses Pemilu. Harapan penulis adalah terjadinya pembelajaran aktif, kreatif dan menyenang kan serta lebih bermakna dan adanya keberanian Siswa untuk menyelesaikan masalah kontekstual dengan benar serta untuk lebih menguasai materi pelajaran.

Berdasarkan latar belakang diatas,penulis mencoba menerapkan metode bermain peran untuk meningkatkan hasil belajar siswa Kelas VI Semester I SD Negeri Jango Kecamatan Janapria Kabupaten Lombok Tengah.

\section{Rumusan Masalah}

Setelah menemukan faktor penyebab Siswa belum memahami materi Proses Pemilu pada pelajaran PKn maka rumusan masalahnya adalah: “ Bagaimakah Meningkatkan Hasil Belajar PKn Materi Proses Pemilu Melalui Metode Bermain Peran Siswa Kelas VI Semester I SD Negeri Jango Tahun Pelajaran 2015 / 2016?”.

\section{Tujuan Penelitian}

Tujuan Penelitian ini adalah untuk mengetahui Bagaimakah Meningkatkan Hasil Belajar PKn Materi Proses Pemilu Melalui Metode Bermain Peran Siswa Kelas VI Semester I SD Negeri Jango Tahun Pelajaran $2015 / 2016$

\section{Manfaat Penelitian}

Tindakan yang diberikan dalam dua siklus dapat bermanfaat bagi siswa untuk memberikan latihan/pengalaman untuk menyelesaikan masalah dan meningkatkan prestasi belajar siswa, dan sebagai refrensi bagi guru untuk melakukan pemecahan masalah kelas di sekolah lain dalam rangka meningkatkan kualitas proses dan hasil pembelajaran PKN dengan menggunakan Metodhe Bermain Peran.

\section{KAJIAN PUSTAKA}

\section{Meotdhe Bermain Peran}

Metode bermain peran adalah berperan atau mamainkan peranan dalam dramatisir masalah social atau psikologis.

Bermain peran adalah salah satu bentuk permainan pendidikan yang di gunakan untuk menjelaskan perasaan, sikap, tingkah laku, dan nilai, dengan tujuan untuk menghayati perasaan, sudut pandang dan cara berfikir orang lain (Depdikbud, 1964 : 171).Melalui metode bermain peran Siswa diajak untuk belajar memecahkan masalah pribadi, dengan bantuan kelompok social yang anggotanya teman - temannya sendiri. Dengan kata lain metode ini berupaya membantu individu melalui proses kelompok sosial.

Melalui bermain peran, para Siswa mencoba mengeksploitasi masalah - masalah hubungan antara manusia dengan cara memperagakannya. Hasilnya didiskusikan dalam kelas.Proses belajar dengan menggunakan metode bermain peran diharapkan Siswa mampu menghayati tokoh yang dikehendaki, keberhasilan Siswa dalam menghayati peran itu akan menentukan apakah proses pemahaman, penghargaan dan identifikasi diri terhadap nilai berkembang : Gatot, Muhsetyo, Drs. M.Sc, dkk,( 2007)

\section{Pengertian Prestasi Balajar}

Prestasi Belajar atau Hasil Belajar (Achievement) yang merupakan realisasi atau perkara dari kecakapan-kecakapan potensial atau kapasitas yang di miliki seseorang. Berikut merupakan beberapa definisi tantang prestasi belajar menurut beberapa ahli, yaitu: 1) Sumadi Suryabrata, Prestasi Belajar adalah nilai sebagai rumusan yang diberikan guru bidang 
studi mengenai kemajuan atau prestasi belajar selama masa tertentu. (Sumadi Suryabrata, 1998), (2) Siti Pratini, Prestasi Belajar adalah suatu hasil yang dicapai seseorang dalam melakukan kegiatan belajar. (Siti Pratini, 2005) (3) Kamus Bahasa Indonesia yang dinamakan Prestasi adalah hasil yang telah dicapai, dilakukan, dikerjakan dan sebagainya.

Berdasarkan pendapat para ahli tentang Pengertian Prestasi Belajar, maka dapat disimpulkan bahwa Prestasi Belajar adalah hasil yang dicapai atau ditunjukkan oleh peserta didik sebagai hasil belajarnya yang diperoleh melalui pengalaman dan latihan. Hal ini biasanya berupa angka-angka, huruf, serta tindakan yang dicapai masingmasing peserta didik dalam waktu tertentu.

Dari berbagai pengertian tentang prestasi belajar di atas dapat diambil kesimpulan bahwa sebenarnya Prestasi Belajar peserta didik tidak selamanya merupakan gambaran dari kemampuan yang sebenarnya. Dengan demikian Prestasi Belajar di sekolah tidak selalu di wujudkan dengan kecakapan-kecakapan, namun kecakapan itu hanya merupakan sabagian dari unsur pertumbuhan, dan pembentukan dari suatu prestasi belajar.

\section{METODHE PENELITIAN}

\section{Setting Penelitian}

Penelitian ini adalah penelitian tindakan kelas ( cllas room action) Model yang digunakan dalam penelitian ini adalah model Spiral Kemmis dan Mc Taggart (Suharsimi Arikunto, 2006: 93). Adapun model dan tahap peneltiantindakan dalam setiap siklusnya adalah sebagai berikut: Secara garis besar terdapat empat tahapan yang biasa dilalui, yaitu (1) perencanaan (planning), (2) pelaksanaan (acting), (3) pengamatan (observing), (4) refleksi (reflecting). Seperti gambar dibawah ini.

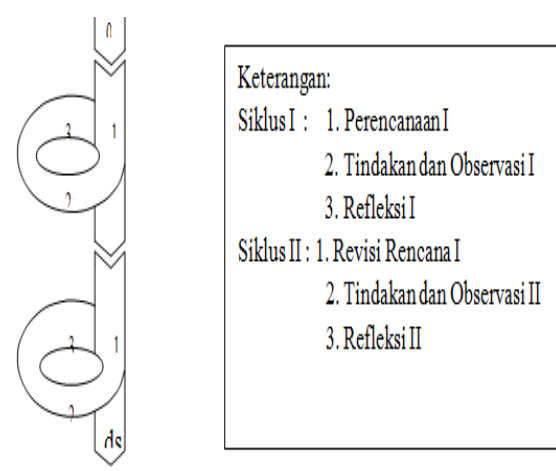

Gambar 1. Penelitian Tindakan Model Spiral Kemmis \& Taggart (Suharsimi Arikunto, 2006:93)

Temapat, Waktu, dan Subyak Penelitian

Tempat yang digunakan untuk melaksanakan penelitian ini adalah SD Negeri Jango Kecamatan Janapria Kabupaten Lombok Tengah pada bulan agustus semster II tahun 2015 pada siswa Kelas VI SD Negeri Jango dengan jumlah siswa 26 siswa, terdiri dari 15 siswa laki-laki dan 11 siswa perempuan.

\section{Teknik Pengumpulan Data}

Teknik pengumpulan data yang digunakan dalam penelitian ini terdiri dari 2 teknik, yaitu teknik observasi dan teknik tes.

\section{Alat Pengumpulan Data}

Alat pengupulan data yang digunakan dalam penelitian ini adalah: a) Butir Soal tes sebanyak 5 nomor, b) Lembar Observasi, yaitu: 1) Observasi terhadap rencana pembelajaran., 2) Observasi terhadap proses pembelajaran. 3) Observasi terhadap hasil yang diperoleh siswa setelah dilakukan tindakan.

\section{Analisa Data}

Teknik analisis data yang digunakan ada yang bersifat kuantitatif dan kualitatif. Data yang diperoleh dikatagorikan dan diklasifikasikan berdasarkan analisis kaitan logisnya, kemudian disajikan secara aktual dan sistematis dalam keseluruhan permasalahan dan kegiatan penelitian.Selanjutnya untuk menganalisis data, hasil tindakan yang dilakukan penulis disajikan secara bertahap sesuai urutan siklus yang telah dilaksanakan, adapun prosedur pengolahan data adalah sebagai berikut : 


\section{HASIL PENELITIAN DAN PEMBAHASAN \\ Kondisi Awal}

Berdasarkan data Tahun Pelajaran 2015/2016, jumlah siswa SDN Jango 321 orang siswa terdiri dari 143 laki-laki dan 178 perempuan, keadaan ekonomi wali murid rata-rata menengah kebawah karena $75 \%$ wali murid berprofesi sebagai Buruh Tani, Pendidikan wali murid rata-rata tamatan Sekolah Dasar, bahkan masih banyak siswa yang ikut bekerja membantu orang tua mencari napkah dan kecerdasan siswa sangat heterogen. Siswa Kelas VI SD Negeri Jango pada Semester I terdiri dari 27 siswa yaitu 15 laki-laki dan 11 Perempuan. Aktivitas siswa dalam pembelajaran Pendidikan Kewarganegaraan, siswa kurang antusias dalam menghadapi pelajaran,terbukti dari hasil pra siklus Dari 26 Siswa hanya 9 Siswa atau 34,62\% yang memperoleh nilai $75 \mathrm{ke}$ atas. Sedangkan 17 Siswa atau 65,38 $\%$ yang mendapat nilai di bawah 75 .

\section{Siklus I}

Tindakan pembelajaran yang akan dilaksanakan adalah dengan menggunakan Metodhe Bermain Peran, siswa dalam kegiatan belajar akan dikelompokkan kelompok, setiap kelompok terdiri dari 5 dan 6 orang, dengan tujuan agar siswa dalam kelompok memperoleh kesempatan yang lebih banyak dalam melaksanakan kegiatan..

Proses pembelajaran pada Siklus I meliputi kegiatan guru dalam mengajar, dan siswa dalam belajar dapat dilihat pada tabel Dari tabel dapat kita lihat Siswa yang mendapat nilai di atasyang memperoleh nilai $\geq 70$ sebanyak 18 Siswa, atau $66,67 \%$ sedangkan yang memperoleh nilai $\leq 69$ sebanyak 9 Siswa atau 33,33\% dari 27 Siswa dengan nilai rata rata 70 dengan nilai terendah 50 dan nilai tertinggi 80 . .

\section{Siklus II}

Proses pembelajaran pada siklus 2 meliputi kegiatan guru dalam mengajar, dan siswa dalam belajar dapat dilihat pada tabel berikut ini :

Berdasarkan data yang terkumpul dari hasil evaluasi yang dilaksanakan pada
Siklus 2, masih banyak siswa yang salah, secara rinci hasil yang diperoleh siswa adalah sebagai berikut : Dari hasil perolehan nilaiyang mendapat nilai $\geq 70$ sebanyak 24 Siswa, atau $88,89 \%$ sedangkan nilai $\leq$ 69 sebanyak 3 Siswa atau $11,11 \%$ dari 27 Siswa,dengan nilai rata rata 76,48 , dengan nilai terendah 60 dan nilai tertinggi 90, ini disebabkan karena pemahaman siswa terhadap materi semakain meningkat.

Tabel; Aktivitas Belajar Siswa Kelas VI dalam Pembelajaran PKN

\begin{tabular}{|c|c|c|c|c|c|c|}
\hline \multirow[b]{2}{*}{ No } & \multirow{2}{*}{$\begin{array}{l}\text { KeterlibatanPeserta } \\
\text { Didik Dalam } \\
\text { Pembelajaran }\end{array}$} & \multirow{2}{*}{$\begin{array}{c}\text { Sebelum } \\
\text { Perbaikan } \\
\text { Jumlan } \\
\text { Siswa } \\
\end{array}$} & \multicolumn{2}{|c|}{ Siklus I } & \multicolumn{2}{|c|}{ Siklus II } \\
\hline & & & $\begin{array}{l}\text { Jumlah } \\
\text { Siswa }\end{array}$ & $\%$ & $\%$ & \\
\hline & & 3 & 19 & $70,37 \%$ & 24 & $88,89 \%$ \\
\hline & Terlibat Pasif & & & 22,22 & 1 & \\
\hline & Tidak Terrilibat & 20 & 2 & $7,41 \%$ & 1 & $3,70 \%$ \\
\hline & Jumlah & 26 & 26 & $100 \%$ & 26 & $100 \%$ \\
\hline
\end{tabular}

Berdasarkan tabel diatas terlihat bahwa jumlah siswa dan persentase siswa yang terlibat aktif dalam pembelajaran sebelum perbaikan pembelajaran menunjukkan adanya kenaikkan, sebelum perbaikan pembelajaran siswa yang terlibat aktif hanya 3 orang $(11,11 \%)$ kemudian naik pada siklus I menjadi 19 orang $(70,37 \%)$.Dan pada siklus II naik menjadi 24 orang $(88,89 \%)$. Hal ini menunjukkan bahwa aktivitas belajar siswa dalam pembelajaran PKN mengalami peningkatan.

Tabel ; Hasil Belajar Siswa dalam Pembelajaran PKN

\begin{tabular}{|c|c|c|c|c|c|c|c|}
\hline \multirow{2}{*}{\begin{tabular}{|c|} 
Internal \\
Nilaial
\end{tabular}} & \multicolumn{2}{|c|}{ Secelum Perbaikan } & \multicolumn{2}{|c|}{ Siklus I } & \multicolumn{2}{|c|}{ Siklus II } & \multirow{2}{*}{ Kategori } \\
\hline & Frekuensi & \begin{tabular}{|l|l|} 
Persen \\
\end{tabular} & Frekuensi & \begin{tabular}{|l|l|} 
Persen \\
\end{tabular} & Frektuensi & \begin{tabular}{|l|l} 
Persen \\
\end{tabular} & \\
\hline $\begin{array}{l}80 . \\
100\end{array}$ & 2 & $7,41 \%$ & 4 & $14,81 \%$ & 22 & $81.48 \%$ & Tuntas \\
\hline $70 \cdot 79$ & 11 & 40,74 & 14 & 51,85 & 2 & 7,41 & Tuntas \\
\hline $60-69$ & 2 & $11,11 \%$ & 4 & $18,52 \%$ & 2 & $11,11 \%$ & tidakKTuntas \\
\hline $40-59$ & 11 & $40,74 \%$ & 4 & $11,11 \%$ & 0 & $0 \%$ & \begin{tabular}{|c|} 
Tidalk \\
Tuntas
\end{tabular} \\
\hline 0.39 & 0 & $0 \%$ & 0 & $0 \%$ & 0 & $0 \%$ & $\begin{array}{l}\text { Tidak } \\
\text { Tuntas }\end{array}$ \\
\hline
\end{tabular}

Dari data di atas dapat terlihat bahwa hasil belajar siswa cenderung meningkat. 
Sebelum perbaikan pembelajaran siswa yang telah tuntas belajar sebanyak 13 orang siswa $(48,15 \%)$ pada siklus I bertambah menjadi 18 orang siswa $(66,67 \%)$ dan pada siklus II menjadi 24 orang siswa $(88,89 \%)$.

\section{Tabel; Lembar Aktivitas Siswa dalam Diskusi Kelompok}

\begin{tabular}{|c|c|c|c|c|c|}
\hline \multirow[t]{2}{*}{$\mathrm{No}$} & \multirow[t]{2}{*}{ Aspek yang Diamati } & \multicolumn{2}{|c|}{ Siklus I } & \multicolumn{2}{|c|}{ Siklus II } \\
\hline & & Frekuennsi & Persentiase & Frekuensis & Persentase \\
\hline 1. & $\begin{array}{l}\text { Mengajukan } \\
\text { Pendapat }\end{array}$ & 5 & $18,52 \%$ & 13 & $48,15 \%$ \\
\hline 2. & Aktif calam Diskusi & 6 & $22,22 \%$ & 14 & $51,85 \%$ \\
\hline 3. & \begin{tabular}{|l|} 
Menjaviab \\
Petranyaan \\
\end{tabular} & 6 & $22,22 \%$ & 15 & $55,56 \%$ \\
\hline 4. & \begin{tabular}{|l|} 
Membantul \\
Mengerjakan Tugas
\end{tabular} & 11 & $40,74 \%$ & 26 & $100 \%$ \\
\hline
\end{tabular}

Dari tabel diatas terlihat adanya peningkatan aktivitas diskusi kelompok mengerjakan LKS.Dalam mengajukan pendapat pada siklus I sebanyak 5 orang $(18,52 \%)$,dan pada siklus II meningkat menjadi 13 orang $(48,15 \%)$.Siswa yang aktif dalam diskusi juga meningkat yaitu pada siklus I sebanyak 6 orang $(22,22 \%)$ dan meningkat pada siklus II meningkat menjadi 14 orang (51,85 \%).Kemudian aktivitas menjawab pertanyaan juga meningkat pada siklus I sebanyak 6 orang $(22,22 \%)$ dan pada siklus II meningkat menjadi 15 orang $(55,56 \%)$.Kemudian akyivitas membantu mengerjakan tugas juga meningkat yaitu sebanyak 11 orang pada siklus I kemudian sebanyak 27 orang (100\%)pada siklus II.

\section{KESIMPULAN DAN SARAN}

Pada pra Siklus jumlah siswa yang tidak tuntas dalam mengikuti pembelajaran 13 orang siswa. Setelah dilaksanakan perbaikan pembelajaran pada Siklus 1 nampak sekali peningkatan hasil belajar siswa yaitu sebesar $66,67 \%$, atau 18 siswa, sudah tuntas dan 9 siswa masih belum tuntas. Pada siklus 2 mengalami peninkatan secara signifikan dimana siswa yang tuntas belajar sebesar $88,89 \%$ atau 23 orang siswa dan yang belum tuntas sebanyak 3 orang siswa atau $11,11 \%$. Berdasarkan uraian pembahasan dan hasil penelitian di atas mulai Siklus 1 sampai siklus 2 mengenai penggunaan Metodhe Bermain Jurnal Ilmu Sosial dan Pendidikan
Peran, dapat peneliti simpulkan bahwa: 1 . Dengan menggunakan pembelajaran Bermain Peran, mampu meningkatkan prestasi belajar siswa Kelas VI SD Negeri Jango pada materi Proses Pemilu. 2. Melalui pembelajaran Bermain Peran, siswa dapat lebih aktif dalam kegiatan belajar

Berdasarkan kesimpulan di atas serta hasil perbaikan dan pembelajaran, agar kegiatan belajar mengajar Pendidikan Kewarganegaraan yang membahas mengenai "Proses Pemilu" anak lebih aktif, kreatif dan memberikan hasil yang optimal bagi siswa. Maka ada beberapa saran yang dapat disampaikan sebagai berikut: 1. Dalam kegiatan pembelajaran PKN sebaiknya guru menggunakan Metodhe Bermain Peran, karena dengan model pembelajaran tersebut dapat meningkatkan prestasi belajar siswa. 2 . Guru hendaknya menerapkan pembelajaran Bermain Peran, karena dapat mengaktifkan siswa dalam pembelajaran.

\section{DAFTAR PUSTAKA}

Roestiyah. (2001). Strategi Belajar Mengajar. Jakarta: Rineka Cipta.

Markaban, (2006 ).Penelitian Tindakan Kelas. Jakarta: bumi Aksara.

Bell. 1978. 5. Teaching Mathematics: Developing as A Reflective Secondary Teacher

Budiningsih, Asri. (2005). Belajar dan Pembelajaran. Jakarta: PT. Rineka Cipta.

Syah. 2004. Psikologi Pendidikan dengan Pendekatan Baru. Bandung: PT Remaja

Taba dalam Affan..(1990).Generalisasi. Banguntapan Jogjakarta:

Djamarah. (2002). Teori Motivasi, edisi 2 (ed2), Jakarta : PT. Bumi Aksara.

Voigt, R., 1994, Buku Pelajaran Teknologi Farmasi, diterjemahkan oleh: Soendani.

Slavin, Robert E., (1994). Science Instruction ... Rineka Cipta. .

Ratumanan. 2002.Analisis Data Kualitatif (Buku. Sumber Tentang Model Pembelajaran-Model Pembelajaran Baru). Jakarta: UIP. ... 
Marzano. 1992.Pembelajaran Kooperatif. Yogyakarta : Pustaka Pelajar.

Depdiknas-Bapenas-Adicitakaryanusa, 2001. Fuad Ihsan. 2003. .... Mulyani Sumantri \& Johar Permana. 2001.

Dahrendorf, Ralf. 1998. ... S. 2000. Filsafat Ilmu Suatu Pengantar Populer. Jakarta: Pustaka Sinar Harapan

Sumadi Suryabrata. (1998). Psikologi Pendidikan. Jakarta: Raja Grafindo

Siti Pratini. (2005). Psikologi Pendidikan. Yogyakarta: Studing

Bukhari M. (1983). Teknik-Teknik Evaluasi Dalam Pendidikan. Bandung: Jemmars

Winkel WS. (1989). Psikologi Pengajaran. Jakarta: Gramedia 